\title{
D.H. Steenberg
}

\section{Negentiende-eeuse Realisme: Hildebrand, Conscience, Cachet}

\begin{abstract}
To date literary historians have not reported extensively on the connection between Dutch and early Afrikaans prose texts of the nineteenth century. This paper endeavours to verify definite intertextual links between an Afrikaans prose text, "Die geldduiwel" (1882-1889) by Jan Lion Cachet and two comparable Flemish and Dutch texts, namely De geldduivel (1856) by Hendrik Conscience, and "De familie Kegge" (1839) by Hildebrand. The most important characteristics of nineteenth century Realism serve as basis for comparison. The resemblances extend far beyond the common themes exhibited by these texts and also include the tendency of artistic texts to approximate reality by representing a total and objective view of particular the bourgeois-centered orientation of the prose in general and the representation of a specific society in particular. The paper opens up a perspective on the mode of representation in prose during the period dominated by Realism, and also illustrates and defines the close relationship that existed between nineteenth century Dutch, Flemish and Afrikaans prose art.
\end{abstract}

\section{Motivering}

Dit is 'n leemte dat Afrikaanse literatuurgeskiedenisse min aandag gee aan die verband tussen die eerste Afrikaanse prosastukke en die Nederlandse prosa. J.C. Kannemeyer (1978: 31) maak wel melding van die verband tussen die Nederlandse predikantepoësie van byvoorbeeld Nicolaas Beets en die SuidAfrikaanse Nederlandse digwerk van M.J. Tromp (1808-1854), P.D.M. Huet (1827-1895) en H.F. Schoon (1851-1930). Hy wys ook (1978:66) op "die tipies humorrealistiese styl van Beets met die vermenging van geestigheid en weemoed" in Jan Lion Cachet se reisverhaal Een bezoek bij de Afrikaansche emigranten te St. Januario Humpata (1882). Nader en vollediger verbandlegging tussen die moeder- en dogterletterkunde vanuit 'n gemeenskaplike hoek is na die beste van my wetc ook nie gedoen nie. 
As in ag geneem word dat die negentiende ecu die eeu van die Realisme in die letterkunde van die Afrikaner se stamlande, naamlik Frankryk, Nederland en Engeland was, is Realisme die voor-die-hand-liggende hoek waaruit representasie in vergelykbare Afrikaanse en Nederlandse prosatekste van die negentiende eeu benader kan word. Daar is inderdaad al na Sewe duiwels van Jan Lion Cachet verwys as "die begin van die realisme in die Afrikaanse letterkunde" (Nienaber, 1940:47). Jan Lion Cachet se Sewe duiwels-prosa, wat tussen 1882 en 1898 in Die Patriot en Ons Klyntji verskyn het, kan dan klaarblyklik met vrug vergelyk word met die werk van Nicolaas Beets (Hildebrand) en met 'n verteenwoordiger van die Vlaamse prosa, soos Tony Bergman, wie se roman Emst Staes al die Vlaamse Camera obscura genoem is, of met Hendrik Conscience, skrywer van Vlaamse prosa oor die burgery, wat die oorgang van die Romantiek na die Realisme meegemaak het. Jan Lion Cachet, wat in 1838 in Amsterdam gebore is en in 1861 as gekwalifiseerde godsdiensonderwyser in die Kaap aan wal stap, het waarskynlik baie deeglik kennis gedra van die werk van Hildebrand wat volgens Dekker (1947:XI) baie geliefd was by die Christelike deel van die Nederlandse volk en reeds in 1839 sy prosadebuut (Camera obscura) gemaak het. Ooreenstemmende titels van Cachet en Conscience ("Die geldduiwel"/De geldduivel, 1856) en ooreenstemmende temabehandeling ("Die drankduiwel"/Plaeg der dorpen, 1855) dui op verwantskap tussen die werke van laasgenoemde twee.

\section{Oogmerke met hierdie artikel}

Die oogmerke van hierdie uiteensetting is om die stroming waartoe die werke van Hildebrand, Conscience en Lion Cachet behoort, naamlik die Realisme, toe te lig en dan aan te dui in watter mate die kode van die Realisme in enkele werke van hierdie prosaïste voorkom. Die merkwaardigheid van die verwantskap tussen hierdie drie outerus is dat dit selfs moontlik is om verhale op grond van gemeenskaplike tema te selekteer. 'n Baic aktuele tema in gemeenskappe van die opkomende burgery van die negentiende eeu blyk die tema van rykdom met al sy fasette van gierigheid, sosiale strewe en selfs ellende te wees (Vgl. Wellek, 1975: 241). Daarom val die keuse van verhale vir behandeling hier op "De familie Kegge" (106 bladsye) uit die Camera obscura van Hildebrand, De geldduivel (180 bladsye) van H. Conscience en "Die geldduiwel" ( 40 bladsye) en Jan Lion Cachet.

\section{Oorkoepelende kode van die Realisme}

Realisme kan globaal gesien word as een groot stroom in die woordkuns, met sy eie beperkmg en konvensies, wat gerig is op getrouheid aan die werklikheid tot in die uiterlike besonderhede daarvan. As representasiewyse oorskry realisry e die grense van literêre periodes. Realisme as stroming in die 
letterkunde is egter beperk tot wat as 'n realistiese beweging herken word, naamlik daardie strewe na werklikheidsgetrouheid wat hom in die Europese literatuur vanaf circa 1830 (geknoop aan die dood van die Romantikus Goethe, 1832) tot 1885 openbaar. Die Realisme is meer as die som van 'n paar algemene trekke, en inderdaad 'n representasie van probleme waarmee die woordkunstenaars van hierdie periode in hulle prosa geworstel het. Peter Demetz (1967: 336; vgl. ook Mineke Schipper, 1979: 75) noem die volgende:

1. die vorming van die mens en die mensbeeld in die greep van 'n netwerk van knellende magte (vgl. ook Wellek 1975: 236);

2. die vraag na die tipiese wat die heroïese vervang;

3. die moontlikheid van 'n alomvattende vertelling;

4. die probleem van 'n representasiewyse waardeur die ek 'n wêreld wil dien wat buite die sensibiliteit van die skeppende kunstenaar om geldigheid het. Uit Knuvelder (1973: 85) blyk dat sensibiliteit (gevoeligheid vir indrukke) 'n sleutelwoord in hierdie tyd van opstand teen die rasionalisme was.

Vervolgens word die drie gekose tekste om die beurt uit hierdie vier gesigspunte onder die loep geneem.

\subsection{Die mens gebeeld in 'n netwerk van lewensmagte}

Die periode van die Realisme word voorafgegaan deur 'n herevaluering van die mens en sy verhouding met sy omgewing. Die Romantiese beeld van die mens in isolasie maak plek vir ' $n$ beeld van die mens as resultaat van ontwikkeling in 'n netwerk van lewensfere en historiese tydvakke. Dit hang saam met die sentrale probleemstelling wat die Franse natuurondersoeker graaf G.L.L. de Buffon (1707-1788) in 1749 in sy werk Algemene natuurgeskiedenis stel: Hoe reageer dic lewende wese - en by implikasie die mens - op die veranderinge in sy omgewing? Daaruit word die term milieu deur H. Balzac en $\mathbf{H}$. Taine op die letterkunde oorgedra. Dit lei in die letterkunde tot beelding van die mens as wese wie se konsekwente handeling deur sy verlede en magte in sy bestaansituasie bepaal word.

In die drie tekste wat gekies is, word lede van die negentiende-eeuse burgerklas gebeeld teen die agtergrond van die belangrikste mag in 'n ontwikkelende maatskappy, naamlik geld.

In "De familie Kegge" van Hildebrand gaan dit meer om die status wat rykdom vir Jan Adam Kegge meebring. Hildebrand word deur William Kegge, 'n siek student uit Wes-Indië in Leiden, na sy ouerhuis genooi. Die jong Kegge sterf aan tifus en Hildebrand voel verplig om die doodsberig aan die ouers te skryf en raak so betrokke by die gesin, wat hy later as skatryk Wes-Indiese 
immigrante in Nederland leer ken. Wat Hildebrand in hierdie verhaal beskryf, is die burgerlike Kegge-gesin se reaksie op rykdom wat hulle in die Nuwe Wêreld verwerf het. In die hoogste mate in ooreenstemming met die kode van die Realisme, dra beelding die hoofklem in die Hildebrand-teks, waaroor later meer.

De geldduivel (1856) is een van Hendrik Conscience se burgerlike sedeverhale, wat esteties van baie hoër gehalte is as sy historiese verhale. Hierdie roman is gebou rondom 'n sterker konflik as die werk van Hildebrand en beeld die tweespalt tussen geldsug en digterskap uit. Die outeur verwoord hierdie konflik tussen twee magte by monde van Laura, dogter van die woekeraar Kemenaer:

Er bestaan in de samenleving twee machten, die elkander op aarde de overheid betwisten, namelijk het geld en het verstand; maar de kracht van het geld is zoo onweerstaanbaar en zoo overtreffend dat de geest zich den gewilligen slaaf van het geld moet maken, of hij sterft onfeilbaar van honger of van wanhoop. De kunst is de hoogmoedigste vorm van den geest; in dezen vorm weigert hij hulde aan de macht van het geld te brengen, en het geld wreekt zich. Niets is natuurlijker. (9)

Hiermee is kernmotiewe in die roman verwoord: samenleving, machten, geld, kunst, natuurlijk. Die woorde "samenleving", "machten", "natuurlijk" gee 'n aanduiding van die Realisme-kode wat in die werk aanwesig is. Rondom hierdie konflik word die karakters Kemenaer, Berthold, Monck en die geïdealiseerde Laura Kemenaer gebou. In hierdie werk dien die geldmotief as katalisator in die stryd om waardes - 'n stryd tussen hebsug en kunssin, tussen geldwolf en kunstenaar, waarin laasgenoemde as verteenwoordiger van die visie van die implisiete outeur seëvier.

In "Die geldduiwel" van Lion Cachet word die konflik deur die ouktoriële verteller verwoord as 'n vertelde reaksie van oom Jan nadat hy die briewe in verband met die geldintrige oor grondbesit gelees het:

Nadat hy die twee briewe gelees het, voel oom Jan nie lekker nie. Daar was 'n stryd daarbinne. Gewete en Geldduiwel kry twis. (13)

Opmerklik is die gebruik van die woord "twis", stamverwant aan die woord "betwisten", wat Hendrik Conscience (9) vir die botsing van die magte gebruik. In oom Jan verloor Gewete die twis teen Geldduiwel in die krisis in die rivier waar oom Jan in die water spring om sy wegdrywende banknote te red. Die blootstelling en skok wat hy opdoen, lei daartoe dat hy siek word en intestaat sterf. 


\subsection{Verburgerliking van die prosa}

Dit is 'n erfenis van die tydvak van die Franse Revolusie dat die adellike held, wat bo die alledaagse uittroon, uit die literatuur verdwyn en dat die kleinburger sentraal in die literatuur van die Realisme staan (vgl. Demetz 1967 en Wellek 1975: 223 ev.). Bekende skrywers het baie bewus uitvoering gegee aan hierdie kode. Emile Zola (kyk Wellek, 1975: 247) spreek hom sterk uit oor die relativering, selfs verdwerging van die Romantiese held, ten gunste van die veelheid figure wat die strate van die grootstad bevolk. Walter Scott (kyk Wellek, 1975: 247) dra tot hierdie anti-heroïese neiging by deur enkele tegniese aanpassings in sy historiese romans te maak: hy sien af van historiese name vir sy sentralc figure omdat dit in stryd is met die strewe na die alledaagse en burgerlike. Verder verskuif hy die historiese held wat nog 'n groot naam dra, na die periferic van die gebeure, waar hy slegs een keer kan opduik (ter wille van die volledigheid?).

Die student William Kegge, die armsalige kleinburger wat in die verhaal van Hildebrand in die vreemde Leiden sterf, en daarmee natuurlik ook sy familie, is 'n soort ideale karakter van die Realisme. Van hom sê die verteller van "De familie Kegge" - vroeg in die verhaal: “...toen, tegen kersttijd, de studentenalmanak verscheen, en het verslag gelezen werd, waarin ook enige regels aan de nagedachtenis van William Kegge waren gewijd, was er reeds menig academiebroeder, die al zijn herinneringsmiddelen moest bijeenroepen om zich voor te stellen hoe 'die William Keg' er bij zijn leven had uitgezien" (120).

Net so lag die ryk man Robyn se vriende in De geldduivel by sy begrafnis hardop vir slimmighede in die begrafnisrede en is hy by die neerlaat van die kis reeds vergete, "hun plicht in de oogen der wereld volbracht" (82). Is dit toevallig dat eenvoudiges in die gemeenskap na die begrafnis van oom Jan in "Die geldduiwel" van Lion Cachet meer aan sy geld as aan hom dink, volgens die woorde van die dogtertjie aan die dominee: "Ons is nou ryk, Meneer, Witbooi sê so. Al oom Jan se geld is nou ons s'n. Ek is bly dat hy dood is" (39). Terselfdertyd illustreer dit die ingesteldheid op die sigbare in die negentiendeeeuse tydgees, waaroor later meer.

Met die dood van die held in die literatuur, loop die literêre werke, in besonder verhale, gevaar om hulle avontuurlikheid te verloor. Om dit te voorkom, is in ooreenstemming met die werkwyse van die natuurwetenskaplike, die tipe geskep om die funksie van die held te vervul. Die betekenis van die woord tipe toon 'n duidelike ontwikkeling (vgl. Wellek, 1975: 244). Aanvanklik verwys Schelling daarmee na 'n "groot universele figuur van mitiese omvang", soos Hamlet, 
Falstaff, Don Quijote en Faust. Via H. Balzac se voorwoord tot die Comedie humaine en die prosa van George Sand (1851) ontwikkel dit om te verwys na "navolgbare sosiale model". Hippolyte Taine gebruik tipe as term vir "modelle vir die gemeenskap" in die betekenis van ideale vrou, martelaar, ensovoorts. Ook in Rusland ontwikkel die term tipe vanaf "figure van universele betekenis" (Belinsky, kyk Wellek, 1975: 244) na "sosiale modelle" wat vir didaktiese doeleindes gebruik word (Dobrolyubov, kyk Wellek, 1975: 244). In soverre tipe in die Realistiese werk onafhanklik is van die kunswaarde van die teks en aanspraak maak op algemene herkenbaarheid of objektiewe sosiale waarneming, is dit 'n belangrike aspek van die kode van die Realisme.

Veral vroeg in die Realisme, byvoorbeeld in die Camera obscura van Hildebrand (1839), word estetiese afstand tussen verhaalfiguur en werklikheid geskep deur die tipiese trekke van die karakter. Dit blyk reeds uit die ikoniese aanbod van die gesinsportrette in die voorhuis van die Kegges:

Gelijk bij alle ijdele menschen, hingen ook in deze huiskamer aan den wand de levensgroote en zeer behaagzieke portretten van mijnheer en mevrouw; mijnheer in een almaviva met een zierlijken zwaai gedrapeerd, en een oogopslag als van een aangeblazen dichter; mevrouw zeer laag gekleed, met een dik parelsnoer om den hals, een kanten plooisel om de japon, en schitterende armbanden. (125)

Portrette is ook vir Hildebrand die assosiatiewe skakel tussen die ruimte en Kegge, volgens sy aankondiging van die koms van hierdie karakter:

Ik zocht naar een nieuw onderwerp van gesprek en was juist van plan de portretten te hulp te roepen, als mijnheer Kegge zelf huis kwam. (127)

Wat Hildebrand in hierdie verhaal wil skep, is portrette van Hollandse burgerlike tipes in maatskaplike verband.

Hierdie kode is ingeweef in die selfversekerdheid van die burgerlike Keggefiguur:

Wij in de West zijn familiaar. In Europa is men vrij wat stijver. Je hebt hier adellijke heeren en groote hanzen; daar behoor ik niet toe; waarachtig niet; ik ben niet van adel; ik ben geen groote hans; ik ben een parvenu, zoo je wilt. (128)

Skamper verwysings na "groote hanzen en adellijke heeren" (221), wat eintlik deur Kegge beny en daarom verkleineer word, vorm 'n refrein in die verhaal. In ooreenstemming hiermee kom die heer Kegge se pralerigheid uit in die afwysing van alles wat hy nie besit nie en die inventarisering van alles wat hy wel besit. Boekgeleerdheid behoort tot eersgenoemde en word geëtiketteer met 
die tweede refrein in hierdie verhaal: "allemaal gekheid": "Dat lange schoolgaan - allemaal gekheid" (130). Tog staan hierdie afwysing van hoë dinge nie los van 'n duidelike trots op sy burgerlike eie nie, soos blyk uit die wyse waarop hy die geleerddoenery van Barend, die bloemistekneg, "een man van een, in zijn stand, allerwaardigst voorkomen", afwys: "Hou op met je potjes-latijn! Hoe heet het in je moers taal, man?" (151). As kind van sy tyd en stand is Kegge gesteld op uiterlikhede, wat hy "alles onder even drukke en schutterige gesprekken" lukraak opnoem en daarmee uitvoering gee aan die ironiseringsproses in die verhaal:

... mijn vrouw verstaat geen woord Fransch, en toch heeft ze elf kinderen gehad, weetje... Zie je dien opgezetten tijger? Die heb ik zelf op mijn zuikerplantage geschoten!... De deugnict had al drie maal een kalf komen weghalen. (131)

Hierteenoor blyk soms met 'n tikkie humor, fyner trekkies van Kegge wat hierdie uiterlike temper, soos sy begerigheid dat sy dogter in aanraking kom met die De Groots uit die hoër burgery, die wyse waarop hy die gestorwe William uiterlik uit sy gesprekke weer, maar tog 'n enkele keer aan sy vrou vra hoe oud die seun sou gewees het as hy geleef het. Grootmoeder sien hierdie paradoks in hom raak en knoop dit onder andere aan 'n aspek van die negentiende-eeuse mannekultus, naamlik dat 'n man nie met 'n traan betrap mag word nie:

Kegge is een goed mensch! Hij is goed, hij is hartelijk, hij is week. Maar hij is vol valsche schaamte; hij wil nooit met een traan gezien worden. Hij verdrijft zijn beter gevoel door luidruchtigheid. (171)

Hoe staties die karakter van Kegge en sy gesin is, blyk uit die woord "tafereelen" (220), wat Hildebrand kies om sy Kegge-teks mee te tipeer.

Ook Hendrik Conscience is bekend vir sy deurskouing van die kleinburger. Wat De geldduivel ryker maak as van sy ander werke, is dat hy teenoorstaande tipes in die vermoënde burgerstand daarin beeld. Ten aanvang reeds stel Conscience twee uiteenlopende tipes "lieden" teenoor mekaar:

Het is voor ons geslacht eene droevige betekenis, dat er lieden zijn, die lang hebben geleefd en echter sterven, zonder cene enkele maal den dageraad van eenen schoonen dag te hebben aanschouwd en bewonderd. (2)

teenoor:

Ongetwyfeld, velen ook ontwaken dagelijks bij den eersten morgenschemer; maar het is de noodwendigheid of de zucht naar stoffelijk gewin, die hen ten bedde uitdrijft.

$\mathrm{Zij}$ loopen onachtzaam vooruit, met het hoofd onder zorgen en verdriet gebogen... (2) 
Van die woekeraar Kemenaer sê die verteller in opvolging hiervan nadat sy uiterlike beskryf is: "Waarschijnlijk had hij zijnen mannelijken levensstijl in stoffelijke zorgen gesleten..." (2). Hiermee stem sy siening van die poësie ooreen: “... eene uitspanning, een vermaak gelijk een ander, eene gril der jonkheid” (6). Dit stel hy teenoor rykdom: “... een rijk mensch maakt geene verzen" (6). Daarteenoor staan sy dogter Laura se poësiebeskouing van "Gods werken te bezingen en de zuiverste ontroeringen der menschelijke ziel door de schoonste vormen der taal uit te drukken"(6). Komende van haar, maak die kunsmetafoor die satire waarmee die knoeier Monck getipeer word, des te skerper: "Zijne kunst bestaat in geld uit geld te kweeken, en verschaft deze kunst geen roem, zij geeft rijkdom, aanzien en macht" (7).

Maar Conscience se werk vertoon die verdere dimensie dat dit ook bo die tipiese uitstyg. Ou meneer Robyn het wel die tipiese naam van 'n ryk man, maar hier tree inderdaad 'n oorwinnende uitsonderingsfiguur na vore in die persoon van die digter Berthold Robyn. Kemenaer stel hom duidelik bo die twee dominerende tipes in die romanwêreld van De geldduivel:

Berthold is eene uitzondering; hem wacht een groot fortuin; hij maakt wel verzen, maar daarom is hij toch geen dichter, zooals men het verstaat ... (9)

Dieselfde Kemenaer kom tot insig en inkeer, volgens sy skulderkenning teenoor Berthold:

Ik heb eens in mijn leven uit geldzucht menschen ongelukkig gemaakt. Voortaan wil ik (...) beproefen, of de bron van liefde en levenslust in mijnen boezem nog kan vloeien. (178)

Eensydig tot selfs by die vlak van naïwiteit is die karakter van oom Jan in "Die geldduiwel" van Jan Lion Cachet. Hebsug en hardvogtigheid wat daarmee gepaard gaan, is die kern van die "karakter" oom Jan. In watter mate die geldduiwel van hom besit neem, blyk uit sy noodlottige sprong om sy baadjie met banknote uit die vol rivier te red. Sy geesgenoot, die winkelier wat die woekerveldtog inisieer, dra die tipiese naam van meneer Pay.

\subsection{Strewe na alomvattende representasie}

Die Realis strewe na treffende (Eng. striking - Demetz, 1967: 336), volledige representasie van die alledaagse. Hierdie kode lê opgesluit in die titel Camera obscura, wat verwys na 'n apparaat wat tot 1837 (die ontwikkeling van die hedendaagse kamera) in gebruik was en wat die gebruiker in staat gestel het om 'n saamgeperste kleurbeeld te sien van die landskap waarop die instrument se lens gerig word. Demetz (1967: 336) verwys byvoorbeeld ra die Fransman 
Balzac se "honger na 'n volledige wêreld" op die spoor van die Franse natuurwetenskaplikes. Die leser van Hildebrand en Conscience merk dit onmiddellik in die outeurs se voorliefde vir die opteken van fyn besonderhede van karakters sowel as ruimte. Maar die omvattendheid van representasie het ook te doen met die samehang tussen aspekte van die gerepresenteerde werklikheid. Stendahl (Bol-Johansen, 1979: 6) noem dit die pittoreske perspektief van die Realisme, verwysende na twee soorte samehang, naamlik tussen psigologie en klein uiterlike trekkies, asook tussen landskap (ruimte) en handeling.

Hildebrand (124) gee 'n uitgebreide beskrywing van die voorkamer van die Kegges wat hy betree, met aanduiding ook van die afwesigheid van die portret van sy vriend William tussen die ander omdat William voor die terugkoms na Nederland oorlede is. Mev. Kegge sonder hy uit as "aanmerkelijk bruiner dan haar dochter" en "op dit ogenblik aanmerkelijk verre van een schoonheid in de oogen van een Europeaan" (125). Die grootmoeder is "nog veel bruiner dan mevrouw Kegge" (131), sodat die uiterlike van hierdie vroue die geskiedenis van die Kegges vertel. Geplaas in "een der aanzienlijkste huizen der voorgeborcht" (2), word die Kemenaers en hulle teenspelers in hulle ooreenkomste en afwykings getcken. Die uiterlike van Monck is die duidelikste voorbeeld van ooreenstemming van karakter en voorkoms (7):

Monck was een man van middelmatig gestalte en kon omtrent den ouderdom van veertig jaar bereikt hebben. Wat bij den eersten blik zijn gelaat een zonderling opzicht gaf, was de afwezigheid van haar aan zijne wenkbrauwen en wimpers. (...) In den grond had zijn aangezicht gene hoegenaamde beteekenis; het sprak van niets, en het liet niets vermoeden dan een ootmoedig mens (...) - Zijne kleeding stemde ten volle met de uitdrukking zijns gelaat overeen: een lange frak, onachtzaam gedragen, hing hem bijna tot op de hielen; zijn hoed was sedert lang niet meer nieu; maar zijn halsdoek en zijn linnen waren wit als sneeuw. (7)

Gesigsuitdrukking en kleredrag moet aanduidings gee van die innerlike van die karakter, soos in die geval van meester Koenraad:

Er was in zijne gansche uitdrukking en in zijne gebaren iets ingetogens en zoets, dat het kenmerk van ootmoed en kiesheid droeg. Zijne kleederen stemden overeen met het ambt van pianomeester, dat hij ten huize van mijnheer Kemenaer kwam vervullen. (10)

En:

Berthold (Robyn) was een schoon jongeling met sterk afgeteekende trekken. Zijne wangen waren niet bcroosd; maar toch, de toon van zijn aangezicht was zuiver. Onder zijn verheven voorhoofd glansden twee zwarte oogappels, mild en vurig 
tevens; zijn mond, door nog jonge knevels overschaduwd, trok zich soms tot eene scherpere uitdrukking te zamen, en zware wenkbrauwen plooiden zich wel eens tot diepere gedachten, daar hij beurtelings Laura en haren vader aanschouwde. - In zijne kleeding, in zijne gebaren en in zijnen stillen glimlach zelven lach een toon van losse minnelijkheid en van ingetogene fierheid, die bij den eersten blik kon doen erkennen, dat deze jongeling buiten de ingeborene goedheid des harten ook de fijne wellevendheid der hoogere wereld bezat. (13)

Uiterlike handelinge word beskryf om innerlike belewenis te representeer soos in die volgende:

Die oogen des muzikants schenen met ongemeenen glans te lichten; hij had waarschijnlijk in het boek een stuk aangetroffen dat hem bijzonderlijk behaagde; want zijne lippen bewogen, en hij verroerde de hand tot stille doch krachtige gebaren, als ware hij bezig met in zich zelven de verzen uit te galmen. (13)

In die Cachet-werk is hierdie trek grootliks afwesig. Die teks word oorweldigend gekenmerk deur direkte mededeling. 'n Enkele keer is daar aanduiding dat oom Jan se ruimte aansluit by sy gierige aard, naamlik met die beskrywing van sy plaas en huis:

Op Zaaifontein was dit ook nie alte mooi nie. Daar was wel groot krale en 'n groot stuk land, maar die huis was net soos oom Jan se vader dit eenmaal laat maak het.

Daar was ' $n$ lang gebou met 'n groot voorhuis en twee slaapkamers. 'n Kombuis was daar nie.

“'n Kombuis is te deftig", sê oom Jan. "Daar word ook te veel vuur gemaak". (6)

Voorkoms word ook soms by Cachet gebruik om ironie tot stand te bring, soos die beskrywing van oom Jan by die aanblik van skuldbewyse wat vir hom geld beteken: "Toe oom Jan dit sien, lag hy. Dit wil sê, hy trek sy mond skeef en laat sy tandestompies wys" (8).

\subsection{Buite die sensibiliteit van die kunstenaar: Realisme en objektiwiteit}

'n Wesenskenmerk van 'n teks uit die Realisme is die bewuste verkleining van die afstand tussen representasie en historiese werklikheid. Hierdie objektiwiteit of gebrek aan subjektiwiteit (Wellek, 1975: 247) kom soms neer op die afwesigheid van die skrywer uit sy werk, soos bepleit deur Flaubert en Henry James, of die afwesigheid van die "sensibiliteit" van die skrywer, waarvan Demetz (1967: 336) gewag maak. Hierdie eienskap van onder andere die werke van Shakespeare word deur William Hazlitt aangeprys as "die son van waarheid en natuur" - moontlik die beste formulering van defiksionalisering vir daardie 
tyd. In dic drie werke waarom dit hier gaan, kom dit op verskillende wyses tot uiting.

In "De familie Kegge" word dit nagestreef met 'n logies-saaklike en tegniese skakeling tussen teks en werklikheid. Die outeur begin die verhaal met 'n objektiewe retoriese vraag oor die ontsetting van tifus:

Wie kent niet die ontzettende ziekte, die men in het dagelijksch leven met den gevreesden naam van zenuwzinkingkoorts gewoon is te bestempelen? Wie heeft onder haar geweld geen dierbaren zien bezwijken? Wie heeft haar nimmer bijgewoond $(\ldots)$ ?

Eers hierna betrek die ek-verteller dit op sy eie ervaring:

Voor mij rijst menige angstige herinnering aan hare verschijnselen op. Ik zie nog die lijders, met die gebroken oogen, die zwarte lippen... (116)

So ' $n$ inleiding getuig van die aktualiteit van die siekte in daardie tyd, asook van die feit dat die verteller dit self van naby ervaar het en kan getuig dat tifus noodlottig is. Die ek-verteller se teenwoordigheid word gemotiveer deur sy kontak met William Kegge, seun van die familie, wat die outeur huis toe nooi, maar wat sterf voordat die uitnodiging opgevolg kan word. So word die outeur per skuilnaam Hildebrand uit die werklikheid (aanduiding op voorblad) in die teks ingedra en kan hy met insig maar ook met die nodige afstand (objektiwiteit) oor die situasie in hierdie gesin getuig. Al kom hy dus op uitnodiging by hulle aan huis, is die werklike persoonlike skakel met die familie verbreek met William se dood. Hierdie "onpersoonlikheid" van die vertelling blyk uit Hildebrand se hantering van Jan Adam Kegge wat reeds genoem is. Die feit dat die naam William uit Kegge se woordeskat verdwyn het na sy seun se dood word nie op satiriese wyse teen hom gehou nie, maar met fyn humor gehanteer deur hom net een keer in die hele verhaal sy seun se teoretiese ouderdom te laat oproep.

'n Populêre objektiveringsmiddel wat Hildebrand hicr gebruik, is woordelikse aanhaling van die teks van die uitnodiging (gestuur met Havana-sigare), wat 'n manifestasic is van die onemosioncle vertelhouding wat die verteller van die teks wil handhaaf deur die afwesigheid van enige verwysing na die afgestorwe William of die leed rondom sy dood (121):

Een klein reukoffer van dankbaarheid bij onze komst in het moederland. Kom te $\mathbf{R}$ en vraagt er naar de familie die uit de West is gekomen, en gij sult hartelijk welkom worden geheeten door Jan Adam Kegge. 
Net so word die streekspraak van juffrouw Noriet se hospita (193) met elke fyn nuanse gerapporteer.

\section{Verteller en "waarheid" in die duiweltekste}

Intertekstualiteit is die belangrikste middel waarmee hierdie kode in die twee duiweltekste beslag kry. By Conscience staan die gedigteks "De woekeraar" van die digter Berthold Robyn taamlik sentraal en bevestig die beeld wat die leser van meneer Kemenaer opbou: iemand met veel spanning, min lewensvreugde en geen sin vir skoonheid nie.

In Lion Cachet is dit die briewe van mnr. Pay, die winkelier, en suster Sannie, wat in hul geheel in die teks opgeneem word. Die titels van die werke van Conscience en Cachet dui reeds op 'n standpuntinname van die implisiete outeurs. Die pertinente aanbod van die gedigteks, sowel as die begunstiging van die digter deur die verloop van die verhaal verraai die standpuntinname van die implisiete outeur ten gunste van die digter teenoor die gierigaard, Monck. Die personifiëring van hierdie eienskap tot "duiwel" is egter ook 'n objektiveringsmiddel, in die sin dat dit van die persoon los gemaak word en slegs die geldgierigheidstrek voorwerp van afkeer van die outeur word. By Conscience word hierdie stellingname van die outeur gebalanseer met die inkeer van meneer Kemenaer aan die einde van die verhaal. Daarby word die Conscienceverhaal deur 'n anonieme verteller vertel.

Die verteller in die Cachet-verhaal is ook as onmiddellike waarnemer aanwesig en tree trouens dikwels ekstradiëgeties op. Die volgende gee aanduiding van sy strewe om objektief te skrywe en dit te bewerkstellig deur slegs onbetwisbare waarnemings (objektief) te rapporteer. Hy rapporteer Gerrit se moedeloosheid oor sy siek os deur onder andere gebruik te maak van gedagtepraat (erlebte Rede) (27) en ekstradiëgetiese vertelling:

Hy was alte verdrietig. Sê nou nie: $\mathrm{Ag}$, dis maar wêreldsgoed! Dit is waar, maar as jy jare lank gesukkel het om 'n bietjie bymekaar te bring, dan is dit maar hard wanneer so 'n siekte dit wegneem. Gerrit voel dit diep en daar ek die waarheid wil skrywe, sal ek ook maar sê dat sy oë nat was eer by daarom dink. Hy kon dit nie help nie. Wat moet hy vir Koningsvlei laat weet?

Met “ek... skrywe" versteur die verteller die vertelstroom deur sy waarheidsintensie as deel daarvan te rapporteer.

\section{Samevatting}

Al verskil die gekose tekste van Hildebrand, Hendrik Conscience en Jan Lion Cachet ten opsigte van subgenre, ruimte, gerigtheid en selfs literêre gehalte, is 
hulle volgens die aangeduide ooreenkomste goed met mekaar vergelykbaar. Dit geld die verhaalsituasie in die tekste, waarin die hooffigure gebeeld word as vasgevang in die greep van 'n mag of 'n netwerk van magte. Dit geld ook die beelding van die karakters as tipes. Die karaktertipes van Hildebrand en Conscience toon die grootste diepte, hoewel eersgenoemde staties is soos in 'n sketsverhaal en soos in die Cachetverhaal, terwyl Kemenaer by Conscience ontwikkeling toon. Ten opsigte van die objektivering bestaan die grootste verskeidenheid in hierdie tekste. Dit stem ooreen met die verskeidenheid standpunte wat by verskillende teoretici van die Realisme gevind word.

Oor die algemeen is vergelyking van hierdie drie tekste baie vrugbaar en is daar sterk aanduiding dat hulle gebind word deur die kode van die Realisme as stroming. In hierdie verband kan Jan Lion Cachet gesien word as die begin van die Realisme as stroming, asook van die realistiese representasiewyse in Afrikaans, en kan gesê word dat dit waarskynlik die weg gebaan het vir latere eksponente van die Realisme soos Johannes van Melle, en van die realisme van die populêre prosa tot vandag.

\section{Bibliografie}

Primêre bronne

Conscience, Hendrik. 1879. De geldduivel. Leiden: A.W. Sijthoff.

Hildebrand (pseud. N. Beets). 1947. De familie Kegge. (In Camera obscura. Pretoria: J.H. de Bussy. p.116-222.)

Lion Cachet, Jan. 1936. Die geldduiwel. (In Sewe duiwels en wat hulle gedoen het, deur ou oom Jan. Bloemfontein: Nasionale Pers.)

Sekondêre bronne

Bol-Johansen, Hans. 1979. Stendhal et la notion de mimesis: l'Evolution du réalisme dans les romans Stendhaliens. (In Del Litto, Victor, (red.). Stendhal-Balzac: Réalisme et cinéma. Actes du Xle Congrés international Stendhalien, Auxerre, 1976. Grenoble: Presses Universitaires de Grenoble.)

Dekker, G. (red.). 1947. Inleiding. (In Hildebrand (pseud. N. Beets). Camera obscura. Pretoria: J.H. de Bussy. p. 1X-XL111.)

Demetz, P. 1967. Zur Definition des Realismus. Literatur und Kritik, 2:333-345.

Jonckheere, W.F. 1968. Johannes van Melle: Realist tussen twee werelden. Pretoria: Van Schaik.

Kannemeyer, J.C. 1978. Geskiedenis van die Afrikaanse literatuur I. Pretoria: Academica. Knuvelder, G.P.M. 1973. Handboek tot de geschiedenis der Nederlandse letterkunde, deel

3. Den Bosch: Malmberg.

Nienaber, P.J. 1940. Jan Lion Cachet met sy sewe duiwels. Pretoria: Van Schaik.

Schipper, Mincke. 1979. Realisme. De illusie van werkelijkheid in de literatuur. Brugge: Orion.

Wellek, R. 1975. Concepts of criticism. London: Yale University Press.

\section{Potchefstroomse Universiteit vir CHO}

